\title{
Usefulness of Mathematics Subjects in the Accounting Courses in Baccalaureate Education
}

\author{
Alec John Villamar ${ }^{1}$, Marionne Gayagoy ${ }^{1}$, Flerida Matalang ${ }^{1}$, Karen Joy Catacutan ${ }^{2, *}$ \\ ${ }^{1}$ School of Accountancy, Business and Hospitality, University of Saint Louis, Tuguegarao City, Philippines \\ ${ }^{2}$ Center for Business Research and Development, University of Saint Louis, Tuguegarao City, Philippines
}

Received October 24, 2019; Revised November 15, 2019; Accepted November 19, 2019

Copyright $(2020$ by authors, all rights reserved. Authors agree that this article remains permanently open access under the terms of the Creative Commons Attribution License 4.0 International License

\begin{abstract}
This study aimed to determine the usefulness of Mathematics subjects in the accounting courses for Bachelor of Science in Accountancy. Mathematics subjects, which include College Algebra, Mathematics of Investment, Business Calculus and Quantitative Techniques, were evaluated through its Course Learning Objectives, while its usefulness for accounting courses which include Financial Accounting, Advance Accounting, Cost Accounting, Management Advisory Services, Auditing and Taxation, was evaluated by the students. Descriptive research was employed among all students in their $5^{\text {th }}$-year in BS-Accountancy who were done with all the Accounting Subjects in the Accountancy Program and they all passed the different Mathematics subjects prerequisite to their courses. A survey questionnaire was used to gather data. Using descriptive statistics, results showed that Mathematics of Investment is the most useful subject in the different accounting courses particularly in Financial Accounting, Advance Accounting and Auditing. Further, by using Mean, the results showed that several skills that can be acquired in the Mathematics subjects are found to be useful in accounting courses and the use of the fundamental operations is the most useful skill in all accounting subjects.
\end{abstract}

Keywords Mathematics Subjects, Accounting Subjects, Mathematical Skills, Accountancy Program, Tertiary Education

\section{Introduction}

Accounting Education and the ways to improve it have been a great concern and a big challenge to the University of Saint Louis, one of the universities in the Northern Philippines, especially that the university continuously provides national topnotchers in the CPA Board
Examinations through the years. It is therefore important for the university and the Accounting educators to facilitate high level of accounting education among the students to achieve better academic and professional success. The accounting discipline is highly concerned with an accurate numerical measurement of business transactions. It requires the practitioners to be comfortable with mathematics in general and numbers in particular. The accountants today are required not only to interpret and analyze corporate data but also to report the information. This requires a great deal of talents and skills mainly on mathematics and logic for daily requirement complex analyses. Zandi (2005) concluded that undergraduate accounting students with major in mathematics from pre-university institutes perform better than those with arts or social sciences backgrounds. Therefore, the mathematics perception level could be the main indicator of efficiency and better performance of undergraduate accounting students.

The accounting education and its connection to mathematics have attracted great concerns in the academe over the recent years. The theme of the following related literatures and studies would cover the relationship between mathematics skills and accounting. Clark (2009) explained that the Language of Business is all about solving business problems, be the events that have already happened or things that might happen in the future. Likewise, mathematics is all about "solving problems," such as making forecasts, using assumptions, measuring what has happened, working with many variables, etc. A CPA might use math concepts like statistics to forecast future cash flows based on several different probable scenarios (probabilities), and then use the math concept of "time value of money" to determine the value of those cash flows in "today's dollars." Being able to compare alternatives in "today's dollars" is the principle way businesses make decisions about spending large amounts of money on potential projects. 
The relationship between Mathematics and Accounting was attributed to the heavy reliance on numbers. As a result, students as well as practitioners of accounting should be comfortable with mathematics in general and numbers in particular (Yunker, et al., 2009). Math grade are all significantly positively related to student performance in the financial accounting course (Uyar \& Gungormus, 2005). In the study of Musa \& Ibrahim (2009) revealed that the two subjects are strongly interrelated. It was found that mathematics skills have about $55 \%$ of the variance in Principles of Accounting. Therefore mathematical skills are useful predictors of students' interest and academic success in principles of accounting. It was also proven in the study of Fedoryshyn, et.al., (2010) that there is a strong correlation between arithmetic reasoning skills and a student's final average in the introductory accounting course.

Zandi \& Shahabi (2012) explained the accounting discipline is highly concerned with an accurate numerical measurement of business transactions. It requires the practitioners to be comfortable with mathematics in general and numbers in particular. It also indicates the needs of accounting students for possessing calculation skills and an acceptable level of knowledge in Algebra. Mathematic skills are influential over the accounting discipline outperformance, i.e., the higher the mathematic knowledge, the better the accounting performance. The authors also conclude that students' previous academic caliber strongly affect their performances in accounting courses. Szabo (2014) said that that there are strong parallels between accounting and two important areas of mathematics, the elementary algebra and the calculus. A basic parallel between accounting and algebra is the balance metaphor. The study of mathematics provides an excellent basis for the applied techniques of accountancy and finance (University of Kent).

In the University of Saint Louis, College Algebra, Business Calculus, Math of Investment, Quantitative Techniques for Business are some of the required subjects for accountancy students which entail a lot of mathematics. University student's success in accounting was attributed to spending more study hours in mathematics and statistics (Eskew \& Faley, 1998). The practical contribution of this study is to ascertain whether certain skills developed in mathematics subjects are useful in the accounting subjects.

\section{Materials and Methods}

Descriptive research design was used in this study to determine the usefulness of skills learned from the Mathematics subjects to the Accounting courses for Bachelor of Science in Accountancy. The study was conducted in the University of Saint Louis, one of the universities in Northern Philippines. The respondents of the study were all the 5th-year Accountancy Students who are enrolled and who already finished all the Accounting
Subjects in the Accountancy Program and they all passed the different Mathematics subjects prerequisite to their course. Survey questionnaire was used and is answerable in a 4-point Likert scale with $4=$ Very Useful; 3=Useful; $2=$ Slightly Useful; 1=Not Useful. Using Mean, the usefulness of Mathematics subjects was analyzed. Also, the usefulness of the different skills learned in the different Mathematics subjects were assessed using the same scale. Table 1 presents the list of skills expected to be developed among students in the different Mathematics subjects and these are reflected in the Course Learning Outcomes in the Course Syllabus that are required in every start of the course.

Table 1. Skills expected to be developed in Mathematics subjects

\begin{tabular}{|l|l|}
\hline \multicolumn{2}{|l|}{ College Algebra } \\
\hline Skill 1 & Explaining basic algebra concepts and procedures \\
\hline Skill 2 & The different fundamental operations \\
\hline Skill 3 & $\begin{array}{l}\text { Solving different types of problems by explaining the } \\
\text { different steps involved }\end{array}$ \\
\hline Skill 4 & Applying algebraic concepts to solve real life situations \\
\hline Skill 5 & $\begin{array}{l}\text { Accurately computing problems involving algebraic } \\
\text { expressions }\end{array}$ \\
\hline Math of Investment \\
\hline Skill 1 & Calculating simple interest and compound interest \\
\hline Skill 2 & Choosing and analyzing the best form of investment \\
\hline Skill 3 & $\begin{array}{l}\text { Decision making skills based on their understanding of } \\
\text { mathematics and money concepts involved in credits, } \\
\text { savings, purchases and investments. }\end{array}$ \\
\hline Skill 4 & Managing resources with confidence \\
\hline Skill 5 & $\begin{array}{l}\text { Recognizing the value of honesty, integrity and } \\
\text { trustworthy as future assessors of funds }\end{array}$ \\
\hline Business Calculus \\
\hline Skill 1 & Applying concepts of limit and continuity of a function \\
\hline Skill 2 & Applying the limit theorem \\
\hline Skill 3 & Obtaining the asymptotes of a function \\
\hline Skill 4 & $\begin{array}{l}\text { Interpreting the derivative as a measure of slope and as a } \\
\text { rate of change }\end{array}$ \\
\hline Skill 5 & $\begin{array}{l}\text { Using derivatives as an aid in sketching the graph of a } \\
\text { function }\end{array}$ \\
\hline Skill 6 & Solving business related problems \\
\hline Quantitative Techniques \\
\hline Skill 1 & $\begin{array}{l}\text { Analytical skills in decision-making process } \\
\text { Skill } 6\end{array}$ \\
\hline Skill 3 & $\begin{array}{l}\text { Appreciating the significance of the quantitative methods } \\
\text { to his/her personal life }\end{array}$ \\
\hline Skill 4 & $\begin{array}{l}\text { Values (i.e. accountability, honesty, collaboration, } \\
\text { competence, communication) }\end{array}$ \\
\hline
\end{tabular}

\section{Results and Discussion}

Table 2 shows the different Mathematics subjects and its 
usefulness in the Accounting subjects. As disclosed, the Mathematics of Investment is found to be useful in Financial Accounting, Advance Accounting, and Auditing. Meanwhile, College Algebra is the most useful mathematics subject in Cost Accounting, Management Advisory Services and Taxation. Overall, Math of Investment is found to be the most useful mathematics subject offered in the Accountancy Program. It is with no doubt that Mathematics subjects are important in pursuing Accounting subjects. The basics or fundamental topics learned in the Mathematics subjects are supplemental in learning some Accounting subjects.

If someone wants to become an accountant, then that person needs to have good skills in math. Therefore, it is suggested that students should pay full attention in their classes so they can easily become good accountants in the future and they find no problem in any admission of business school as well. Zandi (2005) concluded that undergraduate accounting students with majors in mathematics from pre-university institutes perform much better than those with arts or social sciences backgrounds. Therefore, the mathematics perception level as well as pre-university's cumulative grade point averages (CGPAs) as the main indicators of efficiency and better performance of undergraduate accounting students. Moreover, Eskew (1998) also concluded in his study that university student's success in accounting was attributed to spending more study hours in mathematics and statistics. In Hartwell, Lightle \& Maxwell (2005) indicated that $75 \%$ of accounting majors students expressed a high level of interest in mathematics, in comparison to only $43 \%$ of other business majors. Such a perception of a relationship between accounting and mathematics was also confirmed by universities through their course structure.

Table 2. Usefulness of Mathematics subjects in Accounting subjects

\begin{tabular}{|c|c|c|c|c|c|c|c|}
\hline Subject & $\begin{array}{c}\text { Financial } \\
\text { Accounting }\end{array}$ & $\begin{array}{c}\text { Advance } \\
\text { Accounting }\end{array}$ & $\begin{array}{c}\text { Cost } \\
\text { Accounting }\end{array}$ & $\begin{array}{c}\text { Management Advisory } \\
\text { Services }\end{array}$ & Auditing & Taxation & Mean \\
\hline College Algebra & 2.792 & 2.740 & $\mathbf{3 . 2 3 8}$ & $\mathbf{3 . 1 5 1}$ & 2.890 & $\mathbf{2 . 7 6 6}$ & 2.929 \\
\hline $\begin{array}{c}\text { Math of } \\
\text { Investments }\end{array}$ & $\mathbf{3 . 0 7 9}$ & $\mathbf{2 . 8 4 5}$ & 3.121 & 3.128 & $\mathbf{3 . 1 0 9}$ & 2.653 & $\mathbf{2 . 9 8 9}$ \\
\hline Business Calculus & 2.013 & 2.006 & 2.057 & 2.031 & 2.009 & 1.906 & 2.004 \\
\hline $\begin{array}{c}\text { Quantitative } \\
\text { Techniques }\end{array}$ & 2.840 & 2.745 & 2.918 & 3.022 & 2.890 & 2.604 & 2.836 \\
\hline
\end{tabular}

Qualitative Description: 1.00- 1.75=Not useful at all; 1.76- 2.50=Not very useful; 2.51- 3.25=Somewhat useful; 3.26- 4.00=Very useful

Table 3. Usefulness of the developed mathematical skills in the accounting subjects

\begin{tabular}{|c|c|c|c|c|c|c|c|}
\hline Skill & $\begin{array}{c}\text { Financial } \\
\text { Accounting }\end{array}$ & $\begin{array}{c}\text { Advance } \\
\text { Accounting } \\
\end{array}$ & $\begin{array}{c}\text { Cost } \\
\text { Accounting } \\
\end{array}$ & $\begin{array}{c}\text { Management } \\
\text { Advisory Services }\end{array}$ & Auditing & Taxation & Mean \\
\hline \multicolumn{8}{|c|}{ College Algebra } \\
\hline Skill 1 & 2.735 & 2.528 & 3.584 & 3.340 & 2.585 & 2.698 & 2.912 \\
\hline Skill 2 & 3.358 & 3.320 & 3.623 & 3.660 & 3.358 & 3.302 & 3.437 \\
\hline Skill 3 & 2.962 & 2.962 & 3.075 & 3.038 & 2.981 & 2.755 & 2.962 \\
\hline Skill 4 & 2.245 & 2.283 & 2.717 & 2.604 & 2.340 & 2.491 & 2.447 \\
\hline Skill 5 & 2.660 & 2.603 & 3.189 & 3.113 & 2.604 & 2.585 & 2.792 \\
\hline \multicolumn{8}{|c|}{ Math of Investment } \\
\hline Skill 1 & 3.660 & 3.0 & 2.925 & 2.925 & 2.547 & 2.925 & 2.676 \\
\hline Skill 2 & 2.962 & 2.566 & 3.057 & 3.245 & 2.981 & 2.302 & 2.852 \\
\hline Skill 3 & 2.943 & 2.792 & 3.170 & 3.170 & 3.019 & 2.472 & 2.928 \\
\hline Skill 4 & 2.547 & 2.642 & 3.151 & 3.075 & 2.642 & 2.302 & 2.726 \\
\hline Skill 5 & 3.283 & 3.226 & 3.302 & 3.226 & 3.358 & 3.264 & 3.277 \\
\hline \multicolumn{8}{|c|}{ Business Calculus } \\
\hline Skill 1 & 1.887 & 1.925 & 2.057 & 1.962 & 1.717 & 1.887 & 1.906 \\
\hline Skill 2 & 1.774 & 1.774 & 1.755 & 1.755 & 1.792 & 1.736 & 1.764 \\
\hline Skill 3 & 1.698 & 1.717 & 1.811 & 1.774 & 1.830 & 1.717 & 1.758 \\
\hline Skill 4 & 2.151 & 2.0 & 2.019 & 1.981 & 2.132 & 1.717 & 2 \\
\hline Skill 5 & 1.830 & 1.887 & 1.792 & 1.925 & 1.925 & 1.830 & 1.865 \\
\hline Skill 6 & 2.736 & 2.736 & 2.906 & 2.792 & 2.660 & 2.547 & 2.730 \\
\hline \multicolumn{8}{|c|}{ Quantitative Techniques } \\
\hline Skill 1 & 2.698 & 2.642 & 3.132 & 3.189 & 2.679 & 2.453 & 2.799 \\
\hline Skill 2 & 3.0 & 3.057 & 3.226 & 3.283 & 3.038 & 2.755 & 3.060 \\
\hline Skill 3 & 3.208 & 2.868 & 2.830 & 2.906 & 3.132 & 2.604 & 2.925 \\
\hline Skill 4 & 3.038 & 2.981 & 3.113 & 3.208 & 3.321 & 2.925 & 3.097 \\
\hline Skill 5 & 2.472 & 2.472 & 2.679 & 2.849 & 2.566 & 2.434 & 2.579 \\
\hline Skill 6 & 2.623 & 2.453 & 2.528 & 2.698 & 2.604 & 2.453 & 2.560 \\
\hline
\end{tabular}

Qualitative Description: $1.00-1.75=$ Not useful at all; $1.76-2.50=$ Not very useful; $2.51-3.25=$ Somewhat useful; $3.26-4.00=$ Very useful 
In Table 3, it shows the skills developed in Mathematics subjects that are useful in the Accounting subjects. In College Algebra, the skill on the different fundamental operations is most useful in all Accounting subjects, while in Math of Investments, the skill on recognizing the value of honesty, integrity and trustworthy as future assessors of funds is the most useful in the Accounting subjects except for Financial Accounting and Management Advisory Services where in the most useful skills are calculating simple interest and compound interest and choosing and analyzing the best form of investment, respectively. In Business Calculus, the skill deemed most useful in all Accounting subjects is solving business. The same skill under Quantitative Techniques is believed to be the most useful in Accounting subjects such as Advance Accounting, Cost Accounting, and Management Advisory. The skill on accuracy, objectivity and timely reporting is useful in Financial Accounting while the values (i.e. accountability, honesty, collaboration, competence, communication) are assessed to be the useful in Auditing and Taxation.

The skills on use of the different fundamental operations, recognizing the value of honesty, integrity and trustworthy as future assessors of funds, solving business related problems, and values (i.e. accountability, honesty, collaboration, competence, communication) that are developed in mathematics subjects are widely used in the field of accountancy. The findings of the study concurs with Clark (2009) who stated that accounting use math to forecast future cash flows based on several different probable scenarios (probabilities), and then use the math concept of time value of money to determine the value of those cash flows in today's dollars. In short, mathematics is indeed useful in accounting. Although most accounting educators readily acknowledge that mathematical ability has a significant impact on students' performance in accounting courses, to date no statistical research has appeared that numerically quantifies the effect. The present research does not only confirm the relativity of mathematics skills in accounting but it also provides a result regarding the specific skills developed in each mathematics subject.

Further, the use of basic math skills and initial analysis is ideal to determine correct amounts (Media, 2009; Babalola, 2011; Yunker, et.al, 2009 \& Pritchard, et.al. 2005). In addition, different mathematical models in Quantitative Techniques have been used to address a wide variety of issues in financial accounting (Verrecchia, 2005) which supports the findings of the present study.

\section{Conclusions and Recommendation}

The study concludes that there are several skills that can be acquired in the mathematics subjects that are useful in accounting subjects. Skill on the use of the fundamental operations is the most useful skill in all accounting subjects.
Based on the findings of the study, the following are recommend:

[1] Teachers should focus on the development of skills that are found to be most useful in accounting course. As this focus will help students divert their time to more important subjects/skills they needed in pursuing their chosen course/program.

[2] Investigate the relationship between Mathematics and Accounting performance of students. The present study was not able to assess if there is a relationship of the students' grades in Mathematics subjects and in their Accounting subjects, therefore, such is recommended for further study.

\section{REFERENCES}

[1] Babalola, V. (2011). The importance of mathematics in the recording and interpretation of accounting. International Journal of Financial Economic, 1(4), 103-107

[2] Clark, W. (2009). Why math majors, especially those with good communication skills should consider accounting. Southwest Baptist University

[3] Deeb, C. (2009). The importance of basic math in business. Houston Chronicle, Small Business.

[4] Eskew, R. K. \& Faley, R. H. (1988). Some determinants of student performance in the first college- level financial accounting course. The Accounting Review, 63(1), 137-147.

[5] Fedoryshyn, M. H., Brien, M. O., Hintz. A., \& Bosner. K., (2010). Arithmetical reasoning skills as predictor of success in principles of accounting. Academy of Educational Leadership Journal, 14, 93-106.

[6] Hartwell, C., Lightle, S., \& Maxwell B. (2005). High School Students' Perceptions of Accounting. The CPA Journal, New York.

[7] Introductory Accounting Education. Worthy and James Publishing.

[8] Musa, M. \& Ibrahim, A. (2009). The influence of mathematical skills on students' choice of principles of accounting in selected senior secondary schools in Katsina State, Nigeria. Ahmadu Bello University, Zaria, Nigeria.

[9] Pritchard, R.E., Potter, C.G. \& Saccucci, S.M. (2004). The Selection of a business major: Elements influencing student choice and implications for outcomes assessment. Journal of Education for Business, 79 (3), 152-156

[10] Szabo, N. (2014). From accounting to mathematics. Unenumerated, Forbes Business and Finance Blog Network.

[11] University of Kent. Mathematics and Accounting and Finance. Canterbury, Kent.

[12] Uyar, A. \& Gungormus, A. (2011). Factors associated with student performance in financial accounting course. European Journal of Economic and Political Science, 4 (2). 
[13] Verrecchia, R. (2005). The use of mathematical models in financial accounting. Journal of Accounting Research, 20.

[14] Yunker, P., Yunker, J. \& Krull, G. (2009). The influence of mathematics ability on performance in principles of accounting. The Accounting Educators' Journal, 19, 1-20.

[15] Yunker, P.J., Yunker, J.A., \& Krull, G.W. (2009). The influence of mathematics ability on performance in principle of accounting. The Accounting Education Journal, $19,1-200$.

[16] Zandi, G. \& Shahabi, A. (2012). The relationship between mathematics excellency and efficiency of accounting students. Journal of Modern Accounting and Auditing, 8 (10), 1419-1427. 